by taxing corporate owners as though they were partners, are fraught with tremendous administrative difficulties. Moreover, these proposals would retain the unfairness of arbitrary fiscal year allocation of income without ultimate and certain reconciliation of the individual stockholder's tax "realizations" with his aggregate economic gain or loss on his investment. The only complete solution seems to be the removal of the sources of the inconsistencies, which are the discrimination between capital gains and ordinary income, 99 the "unrealized" gain loophole at death, ${ }^{\text {,0o }}$ and the stress on timing created by the fiscal year allocations of the present system. ${ }^{\text {xo }}$ These changes would of course go far toward revamping the entire income tax, and they have been ably advocated as part of such general proposals. ${ }^{\text {102 }}$ Reform of this scope is, however, improbable in the near future.

\title{
PATENT POOLING AND THE ANTI-TRUST LAWS
}

In that broad field where the policies behind the anti-trust laws and the patent laws clash for supremacy the Supreme Court has for many years moved to extend the scope of the Sherman Act at the expense of claimed rights of the patentee. With the decisions in the Gypsum ${ }^{2}$ and Line Material ${ }^{3}$ cases early in I948 this movement reached its farthermost limits to date. But if these decisions served to tell the patentee what he may not do with his patent, they by no means left clear the area in which a legal monopoly may be validly exploited. The first important district court decision to be rendered since those cases throws a good deal of light on the manner in which the federal courts may be expected to comply with the pronouncements of the high tribunal, and in addition opens up some relatively unexplored corners of the anti-trust domain.

United States v. Carboloy4 provides an opportunity to study the manner in which two patentees, one American and one German, by combining their efforts, were able to achieve virtually complete domination of a new-born industry and

99 Int. Rev. Code \& Ir7, 26 U.S.C.A. \& II7 (I945).

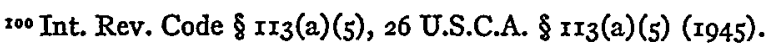

ror Simons, op. cit. supra note 95, at $2 \mathrm{I}-23$.

${ }^{102}$ Simons, Personal Income Taxation (I938); Simons, Federal Tax Reform, I4 Univ. Chi. L. Rev. 20 (1946). The Simons proposals are outlined in Director, Simons on Taxation, 14 Univ. Chi. L. Rev. I5 (I946). Various proposals are discussed in connection with the corporation income tax in Division of Tax Research, Treasury Dept., The Postwar Corporation Tax Structure (1946).

26 Stat. 209 (189o), as amended, I5 U.S.C.A. \$ I (I94I).

$=$ United States v. United States Gypsum Co., 333 U.S. 364 (I948).

3 United States v. Line Material Co., 333 U.S. 287 (I948).

4 United States v. General Electric, Carboloy, Krupp, et al., 80 F. Supp. 989 (N.Y., I948). This case will hereafter be referred to as United States v. Carboloy, and is to be distinguished from United States v. General Electric, 82 F. Supp. 753 (N.J., I949) (incandescent light bulb monopoly), and United States v. General Electric Co., 272 U.S. 476 (rg26) (leading case on patent price fixing). 
retain that control for a period of some twelve years. The industry in question is the manufacture and distribution of hard metal compositions, also known as the cemented carbide field. Hard metal compositions refer to tungsten carbide and to all other combinations of tungsten, tantalum or titanium with carbon, the carbide particles being bound together by iron, cobalt or nickel through a process known as sintering. Cemented carbides have a hardness second only to that of the diamond and find their most important use in tools for cutting and drawing metals and in various machining processes. The carbides are never used alone but always appear as part of a larger tool or die. These materials and processes were developed early in the r920's and there was an almost immediate recognition of their vast potentialities and improvement over existing technology.5 The General Electric Company assumed the task of developing the hard metal compositions in this country. Carboloy was the trade name of the cemented carbide product produced by GE, and the Carboloy Corporation is a wholly-owned subsidiary of GE, created in I928 to exploit the cemented carbide field.

It was the method of exploitation chosen by GE that attracted the attention of the Anti-Trust Division and culminated in I 940 with a criminal indictment under the Sherman Act. Because of the war the trial was postponed until I947. A jury was waived, and in October r 948 a New York federal court found the defendants guilty of eight illegal practices in restraint of trade and guilty on three counts laid under Section 2 of the Act, monopolizing, attempting to monopolize and conspiring to monopolize. Defendants were also convicted on a fifth count charging violation of the Wilson Tariff Act of 1894.7

The Carboloy case was decided against a background that is highly interesting and in some respects unique, and which must be examined briefly in order to understand fully the decision itself.

I

The original United States patents in the cemented carbide field, covering both products and processes, were granted to the Osram Company of Germany in the period I922-25. Osram made a limited assignment to GE for use in the manufacture of electric lamps only, and the remaining rights were assigned to the Krupp Company of Germany. During the ensuing years GE research engineers worked intensively with the material and took out several patents, in-

5 See Hoyt, Tungsten Carbide-A New Tool Material, $\mathrm{r}_{4}$ Trans. of Amer. Soc. for Steel Treating 695 (I928); Status of Tungsten Carbide as a Cutting Material, r23 Iron Age I349 (I929).

${ }^{6}$ Dept. of Justice Release (April 25, 1942); N.X. Times, p. 25, col. 4 (April 26, x942). The postponement was granted in the national interest pursuant to a policy evolved in an exchange of letters between the President, the Attorney General, and the Secretaries of War and Navy. N.Y. Times, p. I, col. 4 (March 29, 1942). See Fisher, Antitrust during National Emergencies: II, 40 Mich. L. Rev. Ir6I, XIgI (I942). The running of the statute of limitations was suspended by 56 Stat. 78 I (1942).

${ }_{2} 8$ Stat. 570 (I894), $x_{5}$ U.S.C.A. $\S 8$ (I94I). 
cluding product and process claims differing substantially from those then held by Krupp. At the same time Krupp was exporting tungsten carbide into the United States under the trade name Widia through two American firms, Union Wire Die Co. and Thomas Prosser \& Sons. These firms manufactured the imported Widia into finished tools and sold them to the trade. Krupp received about $\$ 45$ to $\$ 50$ a pound for the imported material, and on July 7, I928 Krupp and Union Wire Die negotiated a three year contract giving the latter an exclusive option on imported material for use in dies. Prosser handled the material used in the tool line.

By I $928 \mathrm{GE}$ was fully aware of the potentialities of hard metal compositions for machining and wire-drawing purposes. In November of that year a contract was signed by GE and Krupp by the terms of which Krupp assigned to GE all its present and future United States patent rights in the field. Krupp retained only the right to import into the United States under any of the GE-held patents. GE was required to issue a "reasonable" number of nonexclusive licenses to make, use and sell, and was specifically required to so license the Ludlum and Firth-Stirling Companies, with whom Krupp had prior commitments. GE was further required to fix prices and terms of sale and to require all licensees not to undersell GE itself. Krupp agreed that all its imported material would be sold in conformity with GE's prices. A royalty of $\$ 5.00$ per pound was to be charged licensees and go into a royalty fund. GE was to contribute $\$ 5.00$ to the fund for each pound sold and Krupp was to do likewise for each pound imported. Litigation expenses were to be paid from the fund and the remainder of the fund divided between the parties-two-thirds going to Krupp and one-third to GE. The contract was to run for fifteen years with automatic renewals unless terminated by six months' notice, and was pre-dated to April I 7 th in an unsuccessful attempt to make the Krupp-Union Wire Die contract subservient to its price fixing provisions. $^{8}$

The court found that the defendants' primary purpose in entering the agreement was to establish a system of price control ranging over the entire cemented carbide industry.9

\footnotetext{
8 Brief accounts of the cemented carbide pooling arrangements may be found in: United States versus Economic Concentration and Monopoly, Staff Report to the Monopoly Subcommittee of the Select Committee on Small Business, House of Representatives, pursuant to H. Res. 64, 79th Cong., at 2x5 (1947); Stocking \& Watkins, Cartels or Competition? 13I-34 (1948). A more extended account, in the form of a statement by J. H. Lewin of the Anti-Trust Division, can be found in 4 Hearings before a Subcommittee of the Senate Committee on Military Affairs, pursuant to S. Res. I07,78th Cong. rst Sess., at 328 (I943). Facts given below are taken either from the opinion of the court or from I Hearings before Senate Committee on Patents on S. 2303 (Bone Committee), 77th Cong. 2d Sess., at 38-520 (1942).

- United States v. Carboloy, 80 F. Supp. 989, ror6 (N.Y., r948). See also letter from Krupp's American attorneys to Krupp describing a conversation with Morrison of GE: "Each company has something to bargain with and it looks as though there is a real inducement for combining forces since neither company can dominate the situation alone and there is a fair chance that by pooling the patents competition could be discouraged." Ibid., at 995 . Quoted at greater length in PM, p. 6, col. I (Feb. 3, 1947).
} 
A memorandum leading up to the I 928 negotiations, uncovered in the Krupp files after the late war, indicates that Krupp had received oral assurances that it would be consulted by GE before a price was set. ${ }^{{ }^{\circ}}$ Moreover, Krupp expected that the fixed price would be at about the same level as the old price. But immediately after the signing of the contract GE set the price of tungsten carbide at $\$ 453$ a pound-ten times higher than the old price and one and a half times the price of gold. Prices for completed tools were similarly high and were governed by a complicated price manual issued by Carboloy. The manual covered everything except certain "particular tools" which were not price fixed. ${ }^{\mathrm{II}}$ The newly created Carboloy Corporation then established an elaborate "agency" system for the distribution of carboloy tools.

From I928 to I936 GE-Krupp relationships were something less than cordial. Krupp felt that GE's price policy was designed to drive Krupp out of the American market, and in spite of GE's continued requests, refused to bring any pressure to bear upon Union Wire Die Co. to compel that firm to abide by Carboloy's prices. ${ }^{x 2}$ Union did not feel itself bound by the GE-Krupp contract and consequently cut prices whenever it felt it to be advantageous, thereby nearly precipitating a price war and causing Carboloy considerable discomfort. During this period also the metallurgical industries became increasingly aware of the value of cemented carbides, and yet sales were relatively small, over half the production being used by GE itself in its various activities. ${ }^{x_{3}}$ Carboloy found it advisable to grant three additional manufacturing licenses in this period but was also able to cancel the Ludlum license in exchange for the grant of patent rights in another field. Carboloy was also able to reach a sort of precarious working arrangement with Union, an arrangement which the court found to be an illegal price fixing agreement between competitors. ${ }^{{ }^{4}}$

In $1936 \mathrm{GE}$ and Krupp amended their agreement so as to divide world territories between the parties, GE getting the United States and Canada. In return

xo United States v. Carboloy, 80 F. Supp. 989, 996 (N.Y., 1948).

II In the original indictment the government had alleged that Carboloy's motive in setting the price was profiteering. But in a second indictment, returned in 194I, the high price was attributed to a desire by Carboloy to drive Krupp out of the American market by severely restricting sales. Mr. Jeffries, Chairman of the Board of Carboloy, denied this and stated that the price was reasonable in view of the fact that Carboloy, unlike Krupp, was selling a tool service, not just the product. I Hearings before Senate Committee on Patents on S. 2303, 77th Cong. 2d Sess., at 478 (r942). When asked if the price of $\$ 453$ a pound had not shrunk the business volume, Jeffries answered, "No." Ibid., at 507 . Nevertheless there appears little doubt that this price served to restrict narrowly the use of cemented carbides. See the letter from Merrill, a GE engineer, complaining of the high price charged by Carboloy. Ibid., at 94, 99, 385. See also Economic Factors Affecting Use of Tungsten Carbide, 38 Machinery 665 (r932).

12 United States v. Carboloy, note ro supra, at 997 . See also letter from Krupp to GE in March I929. Ibid., at 997 .

${ }^{23}$ I Hearings before Senate Committee on Patents on S. 2303 (Bone Committee), 77th Cong. $2 d$ Sess., at $93-96,385,424$.

14 United States v. Carboloy, note ro supra, at 997 , roro. 
for an increased royalty Krupp agreed not to export into GE territory but retained a veto right over any future licenses to be granted by Carboloy. ${ }^{25}$

Immediately after the signing of this agreement but before it went into effect Carboloy bought out Prosser, Krupp's importer, for a sum $\$ 300,000$ in excess of inventory. Payment was subject to a covenant by Thomas Prosser, the head of the firm, not to compete with Carboloy in the future. A year later Union sold out to Carboloy for $\$ 1, \infty 00, \infty 00$. The court found that these purchases were made pursuant to an understanding between GE and Krupp and for the purpose of eliminating the competition and potential competition offered by the two firms. ${ }^{\text {.6 }}$

As soon as these transactions were completed Carboloy made substantial cuts in the prices of carboloy and carboloy tools-as much as $50 \%$ on some items. Output of tungsten carbide increased considerably in the following years, but production was still only one-eighth that of the German manufacturers and the use of cemented carbides in machining and cutting operations was far more widespread in Germany than it was here. ${ }^{x 7}$ Furthermore, Carboloy had also established the practice of granting substantial discounts in its price manual to large purchasers, a practice presumably induced by the threat of infringement on the part of Ford and General Motors.

Finally, in January of I940, the Firth-Stirling Steel Company, one of the licensees, wrote the Federal Trade Commission complaining of the "unreasonably high prices" and the "unfairness of the discounts" which his license compelled him to charge; prices which were far out of line with production costs. ${ }^{{ }^{8}}$ This complaint served to initiate a grand jury investigation with the return of an indictment on August 30, I940. Four days after the indictment Carboloy announced a drastic cut in price, some tools selling for as little as one-third their previous price. ${ }^{\text {I9 }}$

During all this time GE, which had little confidence in the validity of its pat-

${ }^{15}$ Such territorial division of markets constitutes an illegal restraint of trade. Ibid., at roog. See United States v. National Lead Co., 63 F. Supp. $5^{13}$ (N.Y., 1945), aff'd 332 U.S. 319 (I947); United States v. General Electric Co., 82 F. Supp. 753, 847 (N.J., I949); United States v. Timken Roller Bearing Co., 83 F. Supp. 284, 307 (Ohio, x949); United States v. United States Alkali Export Ass'n, 86 F. Supp. 59, 66 (N.Y., 1949).

${ }^{16}$ United States v. Carboloy, note ro supra, at roog.

17 Hearings, op. cit. supra note 13 , at 89, 381, 382. But Mr. Jeffries maintained that American and German outputs were not properly comparable since the American product was five to ten times as efficient as the German. Ibid., at 479 . This assertion is not sustained in any of the technical articles appearing during this period. Carboloy's research developments apparently did outstrip those of the Germans in the years after I936 however. McKenna, German vs. American Cemented Carbides, 157 Iron Age, No. 6, at 64 (Feb. 7, I946). Germany's greater production may be attributable to its armaments program. Mason, Controlling World Trade I05 (1946).

${ }^{8}$ Hearings, op. cit. supra note $I_{3}$, at $43,218$.

s9 N.Y. Times, p. 34, col. 2 (Sept. 5, 1940). 
ents, took great pains to avoid any adjudication. ${ }^{20}$ But in July of I940 an infringement suit was finally carried through to completion and a Michigan federal district court held six of the basic patents in the pool to be invalid on grounds of prior art.2 The decision was not appealed. The cemented carbide industry thus serves as a striking example of what has long been recognized as one of the major defects of the American patent system: the Patent Office grants too many patents and grants them without adequate investigation. ${ }^{22}$ Much of the monopolistic price fixing present in American industry today is based upon patent structures which may well be invalidated when and if they are adjudicated. Because of the great expense involved in infringement actions many such patents are never litigated, and even if an adjudication is finally reached it may be only after a delay sufficient to permit the "patentee" to have become established in a dominant position in the industry. ${ }^{23}$

In the Carboloy case Chief Judge Knox treated the patents as if they had in fact been valid: "To the defendants' contention that it is harsh to punish them by a criminal conviction for their reliance on the grant given them by the Patent Office, the answer must be that the Patent Office grant did not permit them to conspire together to abuse their patent rights in the manner revealed by this trial." $"{ }^{4}$

The return of the indictment with its disclosure of the GE-Krupp contract

${ }^{30}$ See e.g., letter from Jeffries of Carboloy to Stearns of GE, dated Aug. 8, 1934, in connection with proposed infringement proceedings against Eisler: "The New Jersey district is considered quite unfavorable from the standpoint of patent litigation and we would run the risk of throwing the whole patent situation wide open." Hearings, op. cit. supra note ${ }_{3}$, at 33 r.

${ }^{2 x}$ General Electric Co. v. Willey's Carbide Tool Co., 33 F. Supp. 969 (Mich., I940).

22 In the nine year period from July I940 to July I949 the United States Circuit Courts of Appeal, Courts of Appeal and the Court of Customs and Patent Appeals adjudicated the validity of 552 patents. In 190 of those contests the validity of the entire patent was before the court, and in these instances the patent was held to be invalid 167 times $(88 \%)$, and valid 23 times ( $12 \%$ ). In 362 instances the court was concerned only with the validity of one or more particular claims of the patent in question. The disposition of these cases was as follows: (x) Challenged claim or claims held invalid; 260 (72\%). (2) Challenged claim or claims held valid; $90(25 \%)$. (3) Some claims held valid and some invalid; I2 $_{3}(3 \%)$. Source: West Digest, Fed. Rep. $2 d$ Series, vol. II 3 through $\mathbf{7 5}$. Only those cases where validity or invalidity was actually determined are here considered. The accuracy of these statistics is dependent entirely upon the accuracy of the learned digester, but these results correspond closely to those for years prior to r94I as compiled in Evans, Disposition of Patent Cases by the Courts, $24 \mathrm{~J}$. Pat.

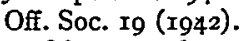

Of course these figures do not purport to indicate that three-fourths of all outstanding patents are invalid since it is probably true that only the weaker patents are ordinarily challenged in the courts. Nevertheless this same factor of selectivity operates with any administrative body - the doubtful or borderline decisions are the ones which are appealed. And on any basis of comparison the appeal record of the Patent Office fares very badly beside that of any other federal administrative agency. See Frank, The United States Supreme Court: $1948-49$, I7 Univ. Chi. L. Rev. I, I9 (I949).

${ }^{23}$ Stedman, Invention and Public Policy, 12 Law \& Contemp. Prob. 649, 658 (1947); Steffen, Invalid Patents and Price Control, 56 Yale L. J. I (I946).

34 United States v. Carboloy, note Io supra, at ror 4 . 
came at a time when Nazi Germany was near the height of its power and when the American defense program was getting into full swing. The Carboloy arrangements attracted considerable popular attention and led to the charge that the American defense effort had been seriously hampered. ${ }^{25}$ In 1942 the Committee on Patents of the United States Senate, under the chairmanship of Senator Bone, conducted hearings on a bill to provide for the use of patents in the interests of national defense. The Committee heard extensive testimony on the Carboloy patent structure. ${ }^{26}$ Zay Jeffries, Chairman of the Board of Carboloy, was given an opportunity to defend the agreements and the Anti-Trust Division introduced a large number of documents subpoenaed from Carboloy's files, documents which later constituted the bulk of government exhibits at the trial.

It is worthy of note that the government chose to institute a criminal proceeding rather than the more usual civil action. ${ }^{27}$ With the collapse of the patent structure in I940 all illegal practices presumably came to an end and the industry was opened to competition. ${ }^{28} \mathrm{~A}$ decree could serve no purpose and the prosecution was carried through only as punishment ${ }^{29}$ and as a deterrent to those who might otherwise be inclined to engage in similar activities. It is believed that the Carboloy case will also prove of considerable value as a precedent.

II

Relying on United States v. Line Material Co., ${ }^{30}$ the court found that the agreement between GE and Krupp, whereby GE was empowered to fix prices under the pooled patents, constituted an illegal restraint of trade. ${ }^{35}$ In the Line Material case two patentees who owned complementary infringing patents which were commercially successful only when used in combination cross-

${ }^{25}$ See e.g., Reimann, Patents for Hitler c. xv (1942). But see Mason, Controlling World Trade 105 (I946): "[T]he effects of the objectionable practices on American industrialoutput were probably moderate, and, on American war preparations, negligible."

${ }^{26}$ Hearings, op. cit. supra note ${ }_{3} 3$.

${ }^{27} \mathrm{~A}$ recent statement by the Anti-Trust Division as to the purpose of criminal prosecutions under the Sherman Act can be found in United States versus Economic Concentration and Monopoly, Staff Report to the Monopoly Subcommittee of the Select Committee on Small Business, House of Representatives, pursuant to H. Res. 64, 79th Cong., at 240 (1947). See also Oppenheim, Cases on Federal Anti-Trust Laws 827 (1948).

${ }^{28}$ See letter, dated Aug. 3 r, I940, from Firth-Stirling to Carboloy announcing intention to lower prices immediately in view of the invalidity of the latter's patents. Hearings, op. cit. supra note 13 , at 371 . It appears that at least some competition does exist today in the cemented carbide industry. See Bertotti, How to Polish Industrial Salesmanship to a Shine, 60 Sales Management, No. $x$, at 69 (Jan. I, I948).

${ }^{29}$ Total fines assessed were $\$ 56,000$. Wall St. J., p. 8, col. 4 (Nov. r 3 , r948). Maximum possible fines were $\$ 175,000$. The government's request for imposition of six month prison sentences on each of the individual defendants was turned down by the court in spite of the argument that fines are considered merely as a license fee and charged off as a cost of doing illegal business. N.Y. Times, p. 30, col. 5 (Nov. $x_{3}$, I948). $^{2}$

${ }^{30} 333$ U.S. 287 (I948).

3r United States v. Carboloy, note to supra, at 1004. 
licensed each other under a royalty-free arrangement whereby one of the patentees was authorized to fix the price at which sub-licensees might sell products manufactured under the combined patents. The royalties obtained from the sub-licensees were to be divided between the two patentees and each of the patentees continued itself to manufacture and sell in accordance with the fixed price. This arrangement was held illegal on the ground that when two or more patentees combine their patents and fix prices on devices produced under any of the patents, competition is impeded to a greater degree than where a single patentee fixes prices for his licensees. Any agreement whereby "patentees in the same patent field arrange for the practice of any patent involved in such a way that royalties or other earnings or benefits from the patent or patents are shared among the patentees ... subjects that contract to the prohibitions of the Sherman Act whenever the selling price, for things produced under a patent involved, is fixed by the contract or a license authorized by the contract." ${ }^{32}$ The Line Material case thus served to restrict narrowly the holding in the leading case of United States v. General Electric, ${ }^{33}$ wherein it was held that a patentee may fix the price at which his manufacturing licensee may sell the patented product, provided the conditions of sale are "normally and reasonably adapted to secure pecuniary reward for the patentee's monopoly." 34

The $1928 \mathrm{GE}-\mathrm{K}$ rupp contract differs in one substantial respect from the contract condemned in Line Material, for Krupp assigned its patents to GE instead of merely licensing them. At first blush it might appear that this fact would bring the contract within the protection of the doctrine of the $1926 \mathrm{General}$ Electric case since Carboloy, as the sole owner of all the pooled patents, would have the right to fix the prices of its licensees even without the contract provision to that effect. The contract serves merely to convert a power into a duty, and in either case the public has no cause to complain of price fixing. Such an interpretation not only begs the question but ignores the rationale of the Line Material case as well.

Both GE and Krupp had an interest in the price fixing provisions. Krupp's interest is evidenced by the royalty-sharing provisions and perhaps also by the right to export which it retained. It is true that Krupp was ultimately disappointed in the operation of the price fixing provisions, but the court was primarily concerned with the expectations of the parties as embodied in the contract itself. GE's interest is apparent from the fact that Carboloy was at the same time a manufacturer and licensor of the patented product and believed that control over the licensee's sale price was necessary to protect its own manufacturing operations and output plans. ${ }^{35}$ The wording of the contract leaves no

${ }^{32}$ United States v. Line Material Co., 333 U.S. 287,315 (1948).

33272 U.S. 476 (1926).

34 Ibid., at 490.

35 Jeffries repeatedly stated before the Senate Committee on Patents that the price fixing provisions were forced upon Carboloy, even going so far as to state that they were the chief disadvantage of the I 928 agreement: "We were the ones that were restricted and persecuted." 
doubt that both parties entered the agreement with the understanding that prices would be set by GE. Without the price fixing provisions there would have been no contract, or so the court must assume. Consequently the mere act of making the contract of assignment is tantamount to an authorization to fix prices within the meaning of Line Material. Moreover, at least in those instances where the agreement to fix prices is a part of the plan to combine, the rationale of Line Material would seem to prohibit any price fixing attempt wherever the patentee has combined his own patents with those obtained from another source even though there is no provision for the sharing of royalties. This is so because the consideration given for the patents so obtained would, in effect, give the assignor or licensor a share in the "benefits" of price fixing. Any other conclusion would not only provide an inducement for holders of weak patents to combine in order to forestall adjudication, but would also provide an easy method for evading the consequences of the Line Material holding, since licensors or assignors would simply capitalize their estimated share of the royalties to be received and take this amount as a lump sum consideration at the time the agreement is made.

Thus all five of Carboloy's licensees promised to cross-license Carboloy under all present or future improvement patents. ${ }^{36}$ These cross-licensed patents would of course be subject to Carboloy's prices since not even their owners would be able to use them apart from the basic patents. The court held these promises condemned by the Line Material case in spite of the absence of any royalty-sharing provisions. The mutual benefit requirement is evidently satisfied by the consideration received by the licensees for their promises to cross-license, namely, the original license from Carboloy.

The Carboloy case, on its facts, represents an extension of the Line Material principle. An agreement to fix prices will now be implied wherever a patent pooling or cross-licensing arrangement is entered into with an understanding by the parties that one of them is to fix prices of sub-licensees under the combined patents, and these price fixing provisions will be condemned even where there is no provision for the sharing of royalties received. In all these respects Carboloy also represents a further narrowing of the doctrine of the General Electric case. The notion that a patentee has the right to fix the price at which a licensee may sell the patented product had its origin in the courts. While Congress has several times declined to overrule it, ${ }^{37}$ that fact can hardly be considered a conclusive

Hearings, op. cit. supra note 13 , at $486,509,515$. This complaint is difficult to understand in view of the fact that the actual price set was deliberately chosen by Carboloy, which had complete discretion in the matter, presumably because it was "reasonable." See note Ir supra.

${ }^{36}$ Two of the licenses provided for cross-licensing only of future patent rights, but the court held these to be indistinguishable from cross-licenses of existing rights insofar as the application of the Line Material doctrine was concerned. United States v. Carboloy, note 1o supra, at 1004 .

${ }^{37}$ See United States v. Line Material Co., 333 U.S. 287 (1948), dissenting opinion at 362 n. 30 . 
reason for retaining it inasmuch as this entire field of law is one traditionally subject to a large degree of judicial legislation. ${ }^{38}$ One way of deciding whether or not the General Electric doctrine should be finally abandoned altogether is to determine how well it has performed the function which is its only excuse for existence-the securing to the patentee of a reasonable pecuniary reward for his invention.

It should be noted at the outset that most patentees today are well aware that the General Electric case hangs on to life by only a slim thread. Presumably they attempt to plan their production and output policies accordingly. ${ }^{39}$ Quite apart from the general incompatibility of price fixing and a freely competitive economy, the Supreme Court has come to look askance upon patent price fixing $^{4^{\circ}}$ because it has so often been used as a means of gaining domination over an entire industry which is then regimented to the patentee's taste. ${ }^{4 \mathrm{I}}$ The General Electric doctrine is usually defended on the ground that it encourages the patentee to adopt a liberal licensing policy with attendant increased production since the patentee need not fear the price competition of his own licensees. In this view, the view adopted in the General Electric case, the patentee receives his reward through his own sales-sales made in a protected market. But it is easily demonstrable that a patentee need not employ the price fixing method in order to secure his reward. The maximum pecuniary reward from the patent may just as well be obtained in the form of royalties received from unlimited licenses not subject to price restrictions. ${ }^{42}$

Licensees, on the other hand, usually stand to gain from participation in a price fixing scheme because they are freed from the inconveniences of competition. But a licensee has no claim upon any of the monopoly profits accruing from the patent. He has invented nothing and society owes him nothing. The con-

${ }^{38}$ The wording of the Sherman Act itself makes it almost inevitable that the courts will supply the largest part of its meaning. With this in mind it becomes less shocking to see the courts insist also on the legislative prerogative of changing the "content" of the statute as time and circumstances change. For an interesting and sometimes illuminating discussion of this subject see Wood, The Supreme Court and a Changing Antitrust Concept, 97 U. of Pa. L. Rev. $3 \circ 9$ (I949).

${ }^{39}$ See e.g., Minnesota Mining in Motion, 39 Fortune, No. 3, at 93, 164 (March 1949).

$4^{\circ}$ Justices Black and Douglas wish to overrule the General Electric case entirely. Chief Justice Vinson and Justices Frankfurter and Burton enthusiastically support the doctrine. Justice Reed is unwilling to overrule it. United States v. Line Material Co., 333 U.S. 287 (I948). Justices Jackson, Clark and Minton have not yet had occasion to state their official views on the matter.

${ }^{41}$ See United States v. Masonite Corp., 3 I6 U.S. 265 (I942); United States v. United States Gypsum Co., 333 U.S. 364 (1948); United States v. Paramount Pictures, Inc., 334 U.S. I3I (I948).

${ }^{42} \mathrm{~A}$ discussion of this point by Aaron Director, Professor of Economics in the Law School of the University of Chicago, will appear in an early issue of the University of Chicago Law Review. See also Justice Douglas' concurring opinion in United States v. I ine Material Co., note 32 supra, at 321 . 
sideration he gives for his license is merely a cost of his doing business and gives him no privilege to share in the patentee's reward. ${ }^{43}$

\section{III}

The licensing policy followed by Carboloy gave rise to another illegal restraint of trade. This policy was summarized by the court as follows: "In general, it may be said that Carboloy issued a license only when it felt it to be expedient, and then did so under such restrictive provisions as could be negotiated." 44 The Ludlum and Firth-Stirling licenses were required by the terms of the 1928 agreement and apart from the price fixing provisions were relatively unrestricted. The three later licenses, to American Cutting Alloy, Fansteel and Eisler, contained severe restrictions as to the types of material which could be produced, and the Eisler license provided for a yearly quota as well.

The license to American was granted so that Carboloy could obtain rights to a superior titanium carbide material under which American held patents. Carboloy claimed that these patents infringed its own, but of course was not anxious to test this in court. The licenses to Fansteel and Eisler were granted under similar conditions. In each case the licensee had been an infringer and Carboloy had begun suit. But by a series of deft maneuvers Carboloy invariably managed to avoid adjudication. ${ }^{45}$ Since the infringers were equally anxious to avoid the expenses of litigation a manufacturing license was the logical compromise. The colorful language of the government that Carboloy "bludgeoned certain competitors into the ring by litigation or its threat" ${ }^{46}$ appears to be somewhat of an exaggeration. Perhaps the biggest whip was in the hands of the licensees.

All five licenses granted by Carboloy contained provisions whereby the licensees promised to cross-license Carboloy under any future acquired patent rights. The price fixing aspects of these promises had already been condemned under the rule of United States v. Line Material Co. Judge Knox then held that the promises themselves constituted a violation of the Sherman Act. In Transparent-Wrap Machine Corp. v. Stokes \& Smith Co.47 the Supreme Court held that the practice of licensing a patent on condition that the licensee assign all improvement patents to the licensor is not illegal per se. But that Court went on to state that where the licensor dominates the industry "the owner of a basic

${ }_{43}$ Theoretically a licensee would make no monopoly profits even under a price fixing scheme since the patentee should be able to extract these in the form of royalties. But the eagerness with which licensees usually embrace price fixing plans indicates a wide gap between theory and practice. Apart from the difficulties of computing such a royalty accurately, the patentee is ordinarily willing to forego some of his potential profits in exchange for the assurance of no infringements or other disturbances.

44 United States v. Carboloy, note ro supra, at rooo.

45 Ibịd., at roor. See note 20 supra.

${ }^{46}$ United States v. Carboloy, 80 F. Supp. 989 (N.Y., 1948), government's Memorandum of Law at $\mathrm{r} 6$.

${ }^{47} 329$ U.S. 637 (1947). 
patent might thus perpetuate his control over an industry long after the basic patent expired. Competitors might be eliminated and an industrial monopoly perfected and maintained. Through the use of patent pools or multiple licensing agreements the fruits of invention of an entire industry might be systematically funneled into the hands of the original patentee." ${ }^{8}$

After finding that Carboloy exercised a dominant position in the cemented carbide field ${ }^{49}$ Judge Knox held that these promises to cross-license future patent rights were condemned under the dictum of the Transparent-Wrap case.5o In adopting this position the Carboloy court stated that a majority of the crosslicenses were in effect exclusive and apparently thought that all five licenses must stand or fall together.$^{5 x}$ Given these assumptions there can be little doubt of the applicability of the Transparent-Wrap dictum. The original patentee has used his grant to secure to himself an exclusive right to the practice of a different patent, and if he has made such contracts with a number of licensees the "fruits of invention" will be funneled into his hands just as effectively as if the improvement patents had been assigned to him outright.

Although Judge Knox, either through error or a desire to simplify the problem,,$^{52}$ declined to distinguish between exclusive and nonexclusive licensing-back of improvements, it appears advisable here to give brief consideration to the applicability of the Transparent-Wrap dictum to the case where a basic patentee who dominates an industry licenses his patent subject to a requirement of nonexclusive licensing-back under any improvement patents. Under these circumstances the basic patentee gains no right to exclude others from the practice of any invention after the expiration of his own grant, and it is by no means obvious that he is in a position to "perpetuate his control over an industry." $\mathrm{He}$ has, however, acquired a decided competitive advantage over the other firms in the industry with respect to the use of improvement patents. At the very least the basic patentee will be assured in advance of access to all inventions in the field, an assurance which may serve to open the way for the traditional judicial condemnation of "regimentation." Of greater importance, the basic patentee will almost always have a decided cost advantage over other firms licensed under the improvement. This follows from the fact that the royalty paid by the basic patentee for the use of the improvement has taken the form of a com-

${ }^{48}$ Ibid., at 646.

49 See note 76 infra.

so United States v. Carboloy, nate to supra, at roo6.

${ }^{5 x}$ Four of the five licenses provided for nonexclusive cross-licensing of improvements. But in the course of its discussion of Carboloy's licensing policy the court found that one of these four was "in effect" an exclusive cross-license. No such finding was made with respect to the three remaining licenses. At a later point in the opinion the court states, "In the majority of cases, these licenses, in effect, were exclusive." United States v. Carboloy, note ro supra, at roo5.

${ }^{52}$ See note 5 supra. 
pleted payment, analogous to a flat lump sum, made at the time of licensing the basic patent.s3 Later, when the improvements are made, this sum represents a sunk cost to the basic patentee and he need not take it into account in determining his output under the improvement patent. All other firms making use of the improvement will be paying royalties on a shorter "per period" basis or on a "per unit" basis, and in either case those payments are variable costs which must be taken into account by those firms in making their decisions whether to produce at all, and if so, at what output. ${ }^{54}$

It may well be that these royalty requirements will be such as to discourage all firms other than the basic patentee and the improvement patentee from making use of the improvement. ${ }^{55}$ In such a case the license-back has been in effect exclusive and the Transparent-Wrap dictum should apply. In the event that other firms do decide to take out licenses under the improvement patent the cost advantage enjoyed by the basic patentee may or may not be used to secure and perpetuate a monopoly position. Since the Transparent-Wrap dictum requires an actual, and not merely a theoretical, monopolizing effect, it follows that the legality or illegality of a nonexclusive license-back requirement cannot be determined until after the improvement patent has been taken out and production under it has begun. ${ }^{56}$ This is in contrast to the exclusive license-back arrangement which should be condemned as soon as it is made, provided only that the licensor holds a dominant position in the industry. ${ }^{57}$

53 If the license-back requirement had been omitted from the original licensing agreement then the basic patentee would have been able to command a higher price for the license of his patent. This difference actually represents the consideration for the cross-license of the improvement.

$54 \mathrm{It}$ is conceivable that the original license, instead of providing for "royalty free" use of improvements, may require the basic patentee to pay a fixed royalty to the improvement patentee on a "per unit" or "per period" basis. In such a case the basic patentee would have an option that may result in a decided cost advantage over other licensees of the improvement.

ss Of course it may turn out that the basic patentee has paid too much for the improvement, since such payment was based only on an estimate as to the probable value of future improvements. But even if such is the case the basic patentee will still retain his cost advantage with respect to the use of the improvement, although his assets as a whole may be depleted below those of his competitors.

${ }^{56}$ This is so unless the courts should eventually adopt a prophylactic rule forbidding all license-back arrangements, exclusive or nonexclusive, where a dominant firm is involved.

37 A somewhat different problem arises when the basic patentee does not exercise a dominant position in the industry. This was the actual situation in the Transparent-Wrap case, and the promise to assign future patent rights was there upheld primarily on the basis of the statute which provides for the assignment of patents without any limitations as to what may be valid consideration for such assignment. 29 Stat. 692 (1897), as amended, 35 U.S.C.A. $\$ 47$ (1940). See United States v. Paramount Pictures, Inc., 334 U.S. I3I, I59 (1948). Where the promise is merely to cross-license, this statute would not operate as a buffer to prevent application of the rule prohibiting tie-in sales upon which the licensee had placed his primary reliance in Transparent-Wrap. But it is difficult to see any undesirable consequences from a promise to cross-license nonexclusively under such conditions and, moreover, the Anti-Trust Division has conceded that such a practice would be unobjectionable. Transparent-Wrap Machine Corp. v. Stokes \& Smith, 329 U.S. 637 (I947), brief for the United States as Amicus Curiae, at 14 . 


\section{IV}

The pricing policies followed by the Carboloy Corporation gave rise to still another illegal practice. Carboloy owned both process and product patents for the manufacture of cemented carbides but held no patents on the completed tools in which the carbides were always used. Although the carbide component constituted only between one-third and one-half of the cost of a completed tool, Carboloy required all licensees and agents to abide strictly by the price manual in the sale of completed tools. The price set was computed from estimated average costs and was uniform for all sellers, thereby entirely eliminating price competition..$^{8}$

The court found that Carboloy's attempt to fix the price of the unpatented completed tool went beyond the securing of a reasonable pecuniary reward from the patent" and this holding is based upon the long series of "tie-in" cases. ${ }^{60}$ Certainly it is not surprising that the courts should refuse to permit price fixing beyond the patent area. ${ }^{6 r}$ Only where the unpatented article is substantially the same as the patented component can an argument be made for the right to price fix. Such an argument would be based on an often unnoticed point in the General Electric decision itself, for in that famous case GE had patents only on the filament and the use of gas but was nevertheless permitted to fix the price of the entire light bulb. The Supreme Court contented itself with the statement, in fact incorrect, that " $[t]$ hese three patents cover completely the making of the modern electric lights. . . ."

\section{$\mathrm{V}$}

The Carboloy decision raises once more the problem of the del credere agency. It will be recalled that Carboloy and its licensees distributed their products through a widespread agency system. The agents received both finished tools

${ }^{8}$ As to the lack of competition in the industry, see Hearings, op. cit. supra note $r_{3}$, at 488 . In an interview in May r942 Mr. Robbins, President of Carboloy, stated that "[I]n I938, there were some 97 manufacturers of Carboloy tools in the United States and at no time were all carbide manufacturers under license or price control." 30 Nation's Business, No. 5 , at 72 (May I942). But this ninety-seven obviously includes some of the agents who made only the completed tools from materials furnished by the licensees or by Carboloy itself. Moreover, except for infringers and Union Wire Die Co., all manufacturers were under strict price control, and Union's exemption was not due to any lack of effort on Carboloy's part to bring that firm under control. Hearings, op. cit. supra note I3, at I35-40, 440-48.

59 United States v. Carboloy, note ro supra, at 1005.

60 International Salt Co. v. United States, 332 U.S. 392 (I947); B. B. Chemical Co. v. Ellis, 3 I4 U.S. 495 (I942); Leitch Mfg. Co. v. Barber Co., 302 U.S. $45^{8}$ (r938); Carbice Corp. of America v. American Patent Development Corp., 283 U.S. 27 (I93I).

${ }^{6 x}$ Compare those cases which prohibit the owner of a process patent from fixing the price of the completed product: Sylvania Industrial Corp. v. Visking Corp., I32 F. 2d 947, 955 (C.C.A. 4th, I943); Cummer-Graham Co. v. Straight Side Basket Corp., 142 F. 2d 646 (C.C.A. 5th, r944), cert. den. 323 U.S. 726 (I944); Barber-Colman Co. v. National Tool Co., I36 F. 2d 339 (C.C.A. 6th, 1943); American Equipment Co. v. Tuthill Bldg. Material Co., 69 F. 2d 406 (C.C.A. 7th, 1934). Contra: Straight Side Basket Corp. v. Webster Basket Co., 82 F. 2d 245 (C.C.A. 2d, 1936).

62 United States v. General Electric Co., 272 U.S. 476,48 I (Ig26). 
and unfinished materials from the manufacturers. The finished tools were sold directly to the trade, but most of the unfinished material was manufactured into finished tools by the agents themselves. Except for "particular tools" the agents were required to observe strictly Carboloy's prices and conditions of sale.

The agency system has long been a favorite device of manufacturers who wish to control the price of their product until it reaches the hands of the consumer ${ }^{63}$ while at the same time avoiding the consequences of those decisions which hold that resale price fixing is illegal even where a patent is involved. ${ }^{{ }^{4}}$ The absurdity of permitting legality to depend upon the skill with which counsel can manipulate the terms "agency" and "sale" has long been recognized, ,5 $^{5}$ but it was not until the decision in United States v. Masonite ${ }^{65}$ that the Supreme Court dealt this practice a serious blow. That case held that where the marketing systems utilized by means of the agency agreements are those of the patentee's competitors, and where the purpose is to fix the market price of the competitors and regiment the market, then the scheme violates the Sherman Act since it attempts to enlarge the patent privilege and secure more than the pecuniary reward to which the patentee is entitled.

In applying the Masonite rule to the facts of the Carboloy case Judge Knox followed a two-part procedure. First, the Carboloy agency agreements and practice were compared with that prototype of all valid agency arrangements, that employed by GE in the distribution of electric light bulbs ${ }^{6}{ }^{6}$ The Carboloy agency system was found to be a "pure sham" designed to invoke the rule of the light bulb case. The agents were therefore purchasers and the attempt to fix their sale price constituted illegal.price fixing. ${ }^{68}$

But a determination of the bona fides of the agencies is admittedly unnecessary in applying the rule of United States v. Masonite, for in that case the Supreme Court conceded the validity of the hardboard agencies and yet gave that fact no importance in the decision. Some of the Masonite Company's agents had formerly been competitors of Masonite in the manufacture of hardboard

$6_{3}$ United States v. General Electric Co., 272 U.S. 476 (rg26); United States v. General Electric Co., 82 F. Supp. 753, 8I7 (N.J., I949); Dr. Miles Medical Co. v. Park \& Sons Co., 220 U.S. 373 (IgIr); F.T.C. v. Curtis Publishing Co., 260 U.S. 568 (r923); Appalachian Coals, Inc. v. United States, 288 U.S. 344 (I933); United States v. Masonite Corp., 3 I6 U.S. 265 (r942); Mulholland, Agency as a Concept and Marketing Device under the Anti-Trust Laws, I3 Geo. Wash. L. Rev. 93 (I944).

${ }_{4}$ Bauer \& Cie v. O'Donnell, 229 U.S. I (Igr3); Boston Store of Chicago v. American Graphophone Co., 246 U.S. 8 (rgr8).

${ }^{65} \mathrm{Klaus}$, Sale, Agency and Price Maintenance, 28 Col. L. Rev. 3I2, 44I (I928).

${ }^{66} 316$ U.S. 265 (1942).

${ }_{67}$ United States v. General Electric Co., 272 U.S. 476 (1926). This agency arrangement, with some changes, was recently upheld again on grounds of res judicata. United States v. General Electric Co., 82 F. Supp. 753, 827 (N.J., r949). A typical light bulb agency form is set out in United States v. General Electric Co., 272 U.S. 476 (I926), Transcript of Record at 229. This may be compared with the representative Carboloy agreement found in Hearings, op. cit. supra note 13 , at 354 .

68 United States v. Carboloy, note ro supra, at 1007. 
products, operating under patents which may or may not have infringed those of Masonite. The bulk of Carboloy's agents, on the other hand, had never engaged in the manufacture of cemented carbides, and defendants contended that this was sufficient to distinguish the two cases. But Judge Knox emphasized the fact that Carboloy's agents were long established toolmakers. They purchased cemented carbide material from Carboloy and its licensees and competed with one another and with Carboloy in the manufacture of completed tools. The agency scheme, with its attendant price restrictions, had the effect of completely eliminating price competition from these sales of completed tools. It is this elimination of potential competition through the utilization of competitors' marketing systems that is condemned by Masonite.69

If the Carboloy Corporation wished to engage in the manufacture of completed tools it could have done so by making all such tools itself. But if Carboloy wished to make use of the resources of the many existing toolmakers it could do so only by selling the carbide materials to these toolmakers and taking its profit in the price paid for them. Once having chosen to make use of the existent toolmakers, Carboloy was not permitted to set up an agency scheme in order to eliminate competition among them, for the Masonite case forbids this.

Having held that Carboloy had no right to fix the prices of completed tools, and having held that the agreement among the potential competitors was condemned by Masonite, the Carboloy court proceeded to take a step beyond and held that the agreement among Carboloy and the licensees, by virtue of which no toolmaker could obtain material without signing an agency agreement, constituted an illegal boycott. $7^{\circ}$ This holding is illustrative of the proposition that an agreement among manufacturers not to sell unless the purchaser agrees to abide by an illegal condition is an unlawful boycott. ${ }^{7 x}$ In the past courts have often failed to discuss the boycott issue under these circumstances, presumably because it is merely subsidiary to other restraints of trade. ${ }^{7^{2}}$ Nevertheless it has the support of logic and a certain amount of case law. ${ }^{73}$

\footnotetext{
${ }_{69}$ "The power of Masonite to fix the price of the product which it manufactures, and which the entire group sells and with respect to which all have been and are now actual or potertial competitors is a powerful inducement to abandon competition. . . . The presence of competing patents serves merely to accentuate that tendency and to underline the potency of the forces at work." United States v. Masonite Corp., 316 U.S. 265, 28I (I942). (Italics added.).

Under Judge Knox's view of the Carboloy distribution plan the various toolmakers represented potential competition and the net result of the plan was the combination of these com. petitors into one organization. Compare Justice Douglas' opinion in Standard Oil of California v. United States, 337 U.S. 293, 3 15 (1949).

$7^{\circ}$ United States v. Carboloy, note ro supra, at roog.

${ }^{7 x}$ See Kirkpatrick, Commercial Boycotts as Per Se Violations of the Sherman Act, ro Geo. Wash. I. Rev. 302, 387, 403 (1942).

${ }^{72}$ Thus in Ethyl Gasoline Corp. v. United States, 309 U.S. 436 (I940), the agreement among the licensees not to sell fuel to jobbers who were not approved by Ethyl might well have been denominated an illegal boycott since the condition upon which such approval was grantedprice maintenance-was held to be unlawful.
}

73 Live Poultry Dealers' Protective Ass'n v. United States, 4 F. 2d 840 (C.C.A. 2d, 1924); Jayne v. Loder, I49 Fed. 2 I (C.C.A. 3d, Ig06). 
VI

The final illegal practice found by the court presents a unique problem in the relationship of patent and anti-trust law. As a condition of the 1936 contract amendment Krupp had required that GE make satisfactory arrangements with Krupp's importers, Union Wire Die and Prosser, for the purchase of those two firms. Pursuant to this provision, and for the purpose of eliminating the potential competition which they offered, Carboloy bought out both of these firms for substantial sums. ${ }^{74}$ The completion of these transactions marked the retirement of Krupp from the scene and left the entire American carbide market to Carboloy and its licensees.

Applying the tests of horizontal integration laid down in United States 0. Columbia Steel 75 the court found that these acquisitions resulted in an unreasonable restraint of trade. ${ }^{6}$ But the fact that Carboloy's dominant position was based on patent grants introduces a complicating factor. While a patent grant is by no means a license to "take over" an industry, it is nevertheless obvious that if a firm has a sufficient number of valid patents it will, by virtue of its power to exclude others, exercise a dominant position. Under the r928 GE-Krupp agreement Carboloy obtained the sole right to make, use and vend under all cemented carbide patents. In effect Carboloy then gave Krupp a license to import into the United States. ${ }^{77}$ Prosser and Union existed solely by virtue of Krupp's imports. There could have been no objection if Carboloy, with Krupp's consent, were to have terminated Krupp's license by purchase back or otherwise, even though such action would have the incidental effect of wiping out Prosser and Union. Krupp evidently felt morally obligated to look out for the interests of those two firms, but that fact can hardly have legal significance. As patentee, Carboloy had the privilege of licensing or not licensing as it saw fit. Nevertheless a different result follows when Carboloy directly purchases the two importing firms, and it is not difficult to find the reason.

If Krupp had merely agreed to cease importing into the United States, thereby incidentally cutting off Union's and Prosser's source of supply, the owners of those two firms would have been faced with four alternatives: (I) They might have left the cemented carbide field altogether. (2) They might have accepted

"Carboloy actually maintained that theselarge payments to the two firms were made only at Carboloy's own insistence and out of a sense of fair play, since Krupp would have been willing to eliminate them without any compensation. This interpretation is clearly refuted by documents in the record and was rejected by Judge Knox. United States v. Carboloy, note ro supra, at 999 .

${ }^{75} 334$ U.S. 495 (1948).

${ }^{76}$ Carboloy and its licensees controlled about $75 \%$ of the cemented carbide market. Virtually all of the remainder, except for a few infringers, was controlled by Union Wire Die and Prosser. Prosser was completely subject to Carboloy's prices. Both Union and Prosser did a substantial volume of business, their combined outputs in r935 being about half that of Carboloy itself. United States v. Carboloy, note ro supra, at roro. Hearings, op. cit. supra note I3, at 424 .

77 The nature of an import license is discussed in Becton, Dickinson \& Co. v. Eisele \& Co., 86 F. $2 d 267$ (C.C.A. 6th, 1936). 
some position within the Carboloy Corporation. (3) They might have engaged in research of their own in an effort to secure independent patents and improvements that would enable them to compete with Carboloy. (4) They might simply have begun the manufacture of cemented carbides themselves, thereby forcing Carboloy to bring the patents to adjudication. Because these firms had long experience in the cemented carbide field and were in a position to judge accurately the strength of Carboloy's patents it is very likely that they would have followed one or both of the last two courses. Moreover, the third and fourth alternatives, in contrast with the first two, are socially desirable in the sense that they tend to reduce price to the consumer and eliminate the effects of monopoly..$^{8}$ On the other hand, when Carboloy bought out the two importing firms the third and fourth alternatives were completely foreclosed, particularly since the purchase was subject to a covenant not to compete. ${ }^{79}$ And finally there is the simple point that Carboloy's patents were of only limited duration, whereas by buying out Union and Prosser, Carboloy was able to eliminate their competition for all time. ${ }^{80}$

The Carboloy decision points the way toward a general rule that, in determining the legality of horizontal integrations, a patentee will be subject to precisely the same considerations as would a firm whose dominant position is not due to patent grants. Competition may well exist in spite of a patent structure because of competing patents ${ }^{8 x}$ and because of the ever present possibility that existing grants will be invalidated. ${ }^{82}$ The presence of patents will not blind the courts to these very real possibilities of competition which may be foreclosed by integration. ${ }^{83}$

${ }^{8}$ While this is perhaps obvious with respect to alternative (3) it is equally applicable to (4). The maxim that "thelaw favors compromises" has little place in the patent field. Whether a patent be considered as an incentive for invention or for investment it is, in the last analysis, a grant against the public interest. The frequency with which such awards are invalidated (see note 22 supra) is the best proof of the necessity for continuous intervention by the courts. For a contrary view see Justice Jackson's dissenting opinion in Jungersen v. Ostby \& Barton Co., 335 U.S. 560,572 (I949).

79 The presence of such a covenant was not a conclusive factor in the court's decision. However it did serve as evidence of an "intent to monopolize" which is, in turn, one of the factors to be considered under the Columbia Steel doctrine.

${ }^{80}$ Compare Schine Chain Theaters v. United States, 334 U.S. Iro (I948) (use of monopoly advantage to force a sale condemned under Sherman Act).

${ }^{8 x}$ Even a legal monopolist may be subject to the competition of competing patents and will certainly be subject to the competition of substitute products and services competing for the consumer's dollar. See Chamberlin, The Theory of Monopolistic Competition 57-II6 (6th ed., 1948). For an interesting account of the use of patents in a highly competitive industry, see The New Yorker (April x6, 1949), at x9.

$8 z$ See note 22 supra.

${ }^{83}$ The Carboloy case holding on the integration question thus serves as a necessary complement to the well recognized notion that there may be a monopoly of patents. Standard Sanitary Mfg. Co. v. United States, 226 U.S. 20, 49 (I9I2); Hartford-Empire Co. v. United States, 323 U.S. 386,400 (1945), explained 324 U.S. 570 (x945); United States v. Vehicular Parking Ltd., 54 F. Supp. 828 (Del., I944); United States v. General Electric Co., 82 F. Supp. 753, 805 (N.J., I949). 
After establishing the existence of the eight illegal practices described above, the court experienced little difficulty in finding a conspiracy under Section $x$ of the Sherman Act. ${ }^{84}$ Because of the criminal nature of the case Judge Knox felt it advisable to make a sharp distinction between Section $\mathrm{I}$ and Section 2 of the Act, and conviction on three counts laid under Section 2 followed. Discussion of the problems raised by these findings is beyond the scope of this paper. ${ }^{85}$ It is believed that the particular restraints of trade already discussed represent significant, though not unexpected, developments in a rapidly changing field of the law. Generally speaking, the price fixing powers of the patentee have been further restricted, and at the same time the court has recognized that a patent represents only a limited grant of monopoly power which by no means forecloses the current judicial policy of enforcing competition wherever it is possible to do so.

\section{ACCEPTANCE AND REJECTION IN CONTRACTS BY CORRESPONDENCE}

In a recent Court of Claims case, Dick v. United States, ${ }^{1}$ the court limited the "rule" that a letter of acceptance is "effective" when mailed." The Coast Guard opened negotiation solely with the plaintiff for the purchase of two sets of new type propellers to be used on icebreaking vessels. By mistake, the plaintiff figured his bid on the basis of one set of propellers instead of two. After an exchange of communications, the Coast Guard mailed an offer to purchase the propellers. Shortly after depositing his letter of acceptance in the mail the plaintiff discovered his mistake, and telegraphed a rejection of the offer, which arrived before the letter of acceptance. Relying on a subsequent agreement with the Coast Guard contracting officer, the plaintiff manufactured and delivered the propellers. The government paid for only one set of propellers, claiming that the contracting officer had no authority to modify the contract formed when the letter of acceptance was mailed. In the plaintiff's action seeking payment for the

${ }^{84}$ Relying on Interstate Circuit v. United States, 306 U.S. 208 (1939).

${ }^{85}$ It may be mentioned in passing that all parties placed considerable emphasis on the question of whether the pooled patents were competing or infringing, GE taking the position that they were infringing patents and that therefore some sort of pooling was essential for proper exploitation. If the patents were competing the pool would clearly be condemned by Standard Oil Co. (Indiana) v. United States, 283 U.S. I63, I74 (I93I), since Krupp and GE were dominant firms. Judge Knox found it unnecessary to decide the question inasmuch as the means of exploitation were illegal in any event. Moreover, United States v. Line Material Co., 333 U.S. 287 (1948), casts great doubt over the validity of GE's line of argument, though the problem is admittedly a highly complex one.

$\therefore 82$ F. Supp. 326 (Ct. Cl., I949).

2 It is generally considered that Adams v. Lindsell, r Barn. \& Ald. 68I (K.B., I8I8) established the traditional rule. Compare McCulloch v. Eagle Insurance Co., I Pick. (Mass.) 278 (1822). For a discussion of the early development of the traditional rule in England which was finally settled in Household Fire \& Carriage Accident Insurance Co. v. Grant, 4 Ex. D. 216 ( 1879 ), see Contract by Letter, 7 Am. L. Rev. 433 (1873). For American cases concerning the traditional rule see Williston, Contracts $\$ 81$ (I937). 